\title{
Histone H2A.V Isoform 2
}

National Cancer Institute

\section{Source}

National Cancer Institute. Histone H2A.V Isoform 2. NCI Thesaurus. Code C162834.

Histone H2A.V isoform 2 (114 aa, $\sim 12 \mathrm{kDa}$ ) is encoded by the human H2AZ2 gene. This protein plays a role in nucleosome stability. 